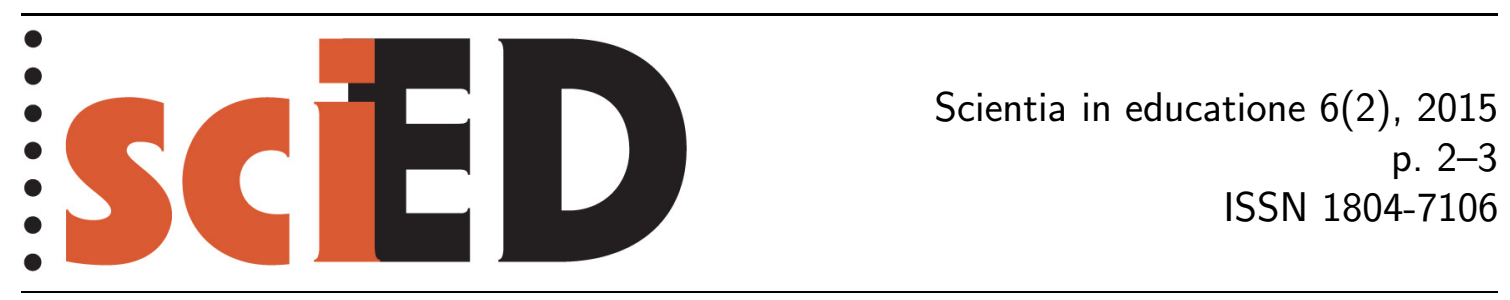

\title{
Úvodník k trojici článků věnovaným disertačním pracím v oboru didaktika biologie, fyziky a chemie
}

\author{
Vojtěch Žák, Martin Rusek, Lenka Pavlasová
}

Zdá se, že oborové didaktiky v České republice v posledních několika letech výrazně ožívají. Přímým dokladem je kniha skupiny (několika desítek) autorů Oborové didaktiky: vývoj - stav - perspektivy. Ta bilancuje zejména vývoj i současnou situaci na tomto poli a zároveň naznačuje, kudy se naše cesty, tedy cesty oborových didaktiků, mohou ubírat.

Každou oblast lidské kultury tvoří lidé a nejinak tomu je i u didaktik přírodovědných oborů. V našem př́padě jsou těmito tvưrci velmi obecně vyučující daných oborů (fyziky, chemie, biologie a zeměpisu) na všech stupních vzdělávání. Určitý kurz vývoje ale udávají zejména lidé vyučující a bádající na pracovištích připravujících budoucí učitele těchto předmětů, tedy na vysokých školách. Ti se typicky rekrutují z řad absolventů doktorského studia daných oborů.

Doktorské studium hraje významnou roli zejména z toho důvodu, že výrazně přispívá ke kultivaci budoucích badatelů v oboru, a tím i k rozvoji oboru v horizontu desítek let. Proto se náš zájem soustředil na doktorské studium, konkrétně na jeho produkty - disertační práce. V následujících třech statích se autoři pokoušejí dílčím způsobem reflektovat disertační práce $\mathrm{v}$ oblasti didaktiky fyziky, didaktiky chemie a didaktiky biologie, které byly obhájeny v České republice v posledních přibližně deseti letech.

Tři analýzy nabídnuté v tomto čísle časopisu Scientia in educatione jsou jedním z počátečních kroků širšího záměru, který by měl směřovat k vytvoření jakési databáze, sítě materiálů a odkazů, která by zahrnovala odborné publikace a jejich zdroje, které považujeme za relevantní v našich oborech. Těmito obory míníme didaktiku fyziky, didaktiku chemie, didaktiku biologie, příp. didaktiky dalších přírodovědných oborů. ${ }^{1}$

Autoři předložených analýz postupovali v zásadě podle shodné metodiky; každý ji však uchopil do určité míry rozdílným způsobem. Autoři shodně shrnují počty disertačních prací obhájených v daných letech, pracoviště, na nichž byly práce vytvořeny, genderové zastoupení autorek a autorů, dále využité metody sběru dat a stupeň vzdělávání, na který jsou disertační práce zaměřeny. Předkládané analýzy mají ovšem určitá specifika.

\footnotetext{
${ }^{1}$ Poslední odstavec berme jako určitý slib; jako se obdobně zavázal jeden z autorů, V. Ž., v časopisu Pedagogická orientace, $24(2)$, s. 240, že bude provedena předkládaná analýza disertačních prací.
} 
$\mathrm{V}$ rámci analýzy disertačních prací z didaktiky fyziky je pozornost zaměřena na léta 2004 až 2013. Analyzován je mimo jiné jazyk, ve kterém je práce napsána, a pozornost je věnována i fyzikálnímu obsahu a šřřeji pojatému zaměření práce z hlediska vzdělávání.

Analýza disertačních prací z didaktiky chemie oproti společnému základu hlouběji analyzuje stupeň vzdělání s důrazem na, v České republice široce diferencované, střední školství. Autor textu vychází z předpokladu, že autocitace v disertační práci odpovídají publikačním výstupům doktorandů. Cást analýzy je proto věnována počtu a kvalitě publikačních výstupů doktorandů.

Do analýzy disertačních prací z didaktiky biologie byly zařazeny i práce zaměřené na didaktiku geologie a ekologie. Důvodem je fakt, že všechny tyto obory spolu tvoří vyučovací předměty pokrývající učivo o živé a neživé přírodě od preprimárního po středoškolské vzdělávání. V období let 2004 až 2013, které bylo záměrně zvoleno stejně jako u didaktiky fyziky, neměla didaktika biologie svůj samostatně akreditovaný doktorský obor a práce byly obhajovány pouze ve studijním oboru pedagogika. Kromě výše uvedených analyzovaných parametrů jsou zmíněny i praktické výstupy prací, které jsou jejich vedlejším produktem.

Provádění reflexí, zejména mají-li shrnovat, hodnotit a být přínosem, je jistým způsobem vstupováním na tenký led. Autoři promítli do koncepce svých statí svoje zkušenosti a je přirozené, že jiní autoři by analýzy pojali více či méně rozdílným způsobem. Smyslem naší koordinované práce, tedy spolupráce tří didaktiků příbuzných oborů, je v tento okamžik zejména podpořit diskuzi o disertačních pracích, a to na podkladě reálných dat, nikoli jen pocitů. 